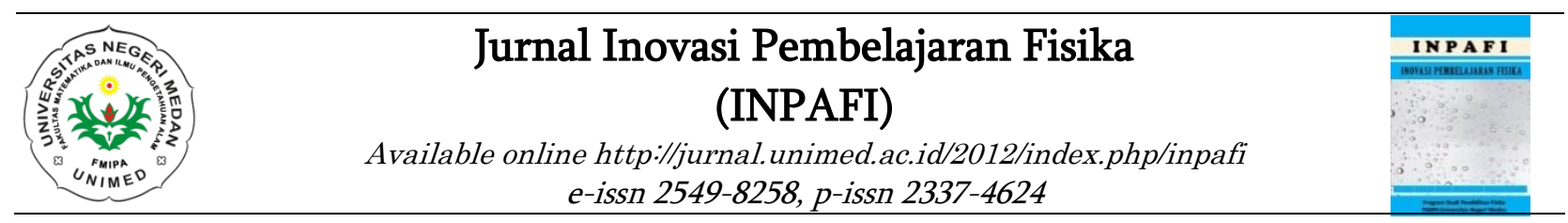

\title{
PENINGKATAN HASIL BELAJAR DENGAN MODEL PROBLEM BASED LEARNING PADA MATERI FLUIDA STATIS
}

\author{
Erwin Manik, Togi Tampubolon dan Junita Simanjuntak \\ Jurusan Fisika FMIPA Universitas Negeri Medan \\ erwinmanik885@gmail.com
}

Diterima: September 2018. Disetujui: Desember 2018. Dipublikasikan: Februari 2019

\begin{abstract}
ABSTRAK
Penelitian ini bertujuan untuk mengetahui pengaruh model problem based learning (PBL) terhadap hasil belajar siswa pada materi pokok Fluida Statis di kelas XI semester II SMA Swasta Raksana Medan T.P. 2017/2018. Jenis penelitian ini adalah quasi exsperiment. Desain penelitian yang digunakan adalah two group pretest-posttest. Populasi dalam penelitian adalah seluruh siswa kelas XI yang terdiri dari 3 kelas yang dipilih dengan cara teknik random sampling. Kelas XI IPA 1 sebagai kelas eksperimen yang berjumlah 35 orang dan XI IPA 2 sebagai kelas kontrol yang berjumlah 31 orang. Instrumen yang digunakan essai dengan jumlah 8 soal yang telah dilakukan uji persyaratan tes untuk mengukur hasil belajar. Hasil penelitian menunjukkan bahwa nilai rata-rata pretest kelas eksperimen sebesar 11,18 dan kelas kontrol sebesar 11,29. Uji t menunjukkan bahwa kemampuan awal siswa kedua sampel. Nilai rata-rata postes kelas eksperimen sebesar 77,39 dan kelas kontrol sebesar 68,71. Uji t menunjukkan ada pengaruh yang signifikan akibat penerapan model problem based learning (PBL) terhadap hasil belajar siswa pada materi pokok Fluida Statis.
\end{abstract}

Kata kunci : Problem based learning (PBL), hasil belajar, Fluida Statis

\begin{abstract}
This research aims to know the influence of Problem Based Learning (PBL) model based on student learning outcomes to the matter of basic static fluid in SMA Swasta Raksana Medan T.P 2017/2018. $A$ kind of this research is quasi experiment. The research design used is two group pretestposttest.The population of this research is all students in class XI consisting of three classes. With cluster random sampling technique selected class XI IPA 1 as experiment class which amounted to 35 people and XI IPA 2 as control class which amounted to 31 people. The instrument used about essays with the number of 8 questions that have been tested the test requirements to measure learning outcomes. The results showed that the average value of pretestt experimental class was 11.18 and control class was 11.29. Based two sample t-test result of both classes indicates that the sample have same initial ability. The average value of experimental class posttest is 77,39 and control class is 68,71 . The $t$ test shows that there is a significant influence on the problem based learning (PBL) model of student learning outcomes in Static.
\end{abstract}

Keywords: Problem Based Learning, learning outcome, Static Fluid 


\section{PENDAHULUAN}

Di zaman yang modern ini berkembangnya pendidikan berpengaruh terhadap perkembangan Ilmu Pengetahuan dan Teknologi (iptek). Pesatnya perkembangan iptek tidak terlepas dari kemajuan ilmu fisika yang ditunjukkan dengan temuan baru dalam bidang sains dan teknologi. Fisika menjadi salah satu mata pelajaran yang sangat penting untuk dipelajari di sekolah.

Berdasarkan pandangan global dan historis, ilmu fisika menyediakan metode lebih dinamis dalam membantu manusia menyelesaikan masalah kehidupan yang kompleks. Kenyataannya di sekolah ditemukan banyak siswa tidak tertarik belajar fisika dan tidak memiliki pemahaman setelah belajar fisika (Praharani, dkk, 2015).

Menurut pengamatan dan pengalaman peneliti pada saat melakukan Praktek Pengalaman Lapangan Terpadu (PPLT) tahun 2017 di salah satu SMA, mata pelajaran fisika menjadi mata pelajaran yang memiliki nilai terendah dari mata pelajaran lain dapat dilihat dari hasil ujian harian dan ujian tengah semester yang hanya 10\% mencapai nilai 75 atau Kriteria Kelulusan Minimal (KKM) tiap kelas.

Alasan utama yang menyebabkan rendahnya nilai pelajaran fisika berdasarkan hasil observasi dan wawancara kepada beberapa siswa selama melakukan PPLT adalah siswa menganggap fisika merupakan pelajaran yang sangat sulit dan rumit dipahami karena memiliki banyak rumus dan perhitungan matematis dan siswa pasif dalam proses pembelajaran sehingga membuat siswa jenuh.

Menyikapi masalah tersebut, perlu adanya upaya yang dilakukan guru untuk menggunakan suatu model pembelajaran yang membuat siswa lebih aktif dalam proses pembelajaran yang dapat membangun pengetahuan sendiri.

Salah satu model pembelajaran yang mengarahkan siswa untuk terlibat aktif dalam proses berfikir dan aktif memperoleh pengetahuan adalah model pembelajaran berbasis masalah atau sering diebut problem based learning (PBL). Pembelajaran berdasarkan masalah dapat diterapkan untuk merangsang berpikir tingkat tinggi dalam situasi berorientasi masalah, termasuk di dalamnya belajar bagaimana belajar (Arends, 2008).

\section{METODE PENELITIAN}

Penelitian ini dilaksanakan di SMA Swasta Raksana Medan. Populasi dalam penelitian ini adalah siswa kelas XI IPA semester II SMA Swasta Raksana Tahun Ajaran 2017/2018. Jumlah kelas XI SMA Swasta Raksana terdiri dari 3 kelas.

Sampel dalam penelitian ini terdiri dari 2 kelas yang dipilih secara random sampling yaitu kelas XI IPA 1 sebagai kelas eksperimen dan XI IPA 2 sebagai kelas eksperimen.

Jenis penelitian ini termasuk penelitian quasi exsperiment. Desain penelitian yang digunakan adalah two group pretest-posttest. Langkah-langkah dalam pelaksanaan penelitian adalah sebagai berikut : a). Tahap perencanaan : (1) Melakukan wawancara dengan guru fisika tentang masalah-masalah yang dihadapi siswa dalam belajar. (2) Mempersiapkan materi pembelajaran. (3) Menyusun Rencana Pelaksanaan Pembelajaran (RPP). (4) Menyusun Lembar Kerja Peserta Didik (LKPD); b). Tahap pelaksanaan: (1) Memvalidasi tes/instrumen penelitian (2) Menentu-kan kelas sampel dari populasi yang ada (3) Melaksanakan pretest pada kedua kelas untuk mengetahui kemampuan awal siswa dan pengelompokan siswa sebelum sebelum materi diajarkan. (4) Melaksanakan pembelajaran kepada kedua kelas. Pada kelas eksperimen menggunakan model PBL dan kelas kontrol menggunakan model pembelajaran langsung. (5) Memberikan postes kepada kedua kelas untuk mengetahui hasil belajar; c). Setelah uji hipotesis dapat diambil kesimpulan.

\section{HASIL DAN PEMBAHASAN}

\section{a. Hasil Penelitian}

Awal penelitian kedua kelas sampel diberikan pretest yaitu untuk mengetahui kemampuan awal kedua kelas sampel. Data yang 
Erwin Manik, Togi Tampubolon dan Junita Simanjuntak; Peningkatan Hasil Belajar Dengan Model Problem Based Learning pada Materi Fluida Statis

diperoleh yaitu nilai rata-rata pretest kelas ekperimen yaitu 11,18 dengan standar deviasi 2,62 dan kelas kontrol sebesar 11,29 dengan standar deviasi 2,69. Hasil pretest kedua kelas sampel dapat dilihat dari Gambar 1.

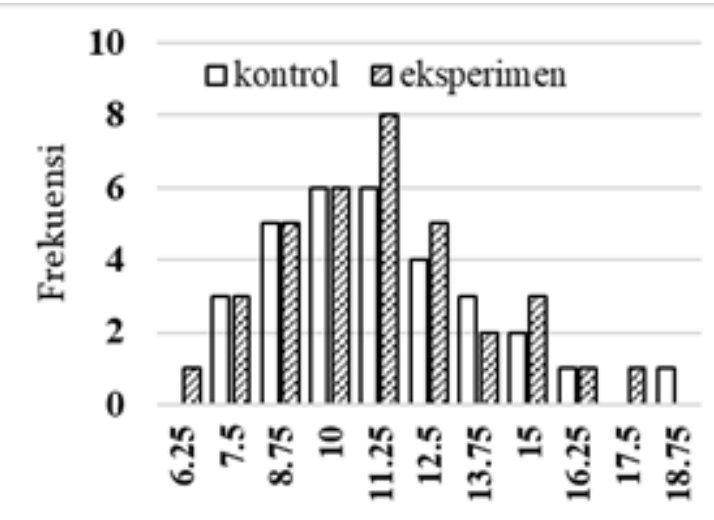

Nilai Pretest kedua kelas

Gambar 1. Data Pre-test Kelas Eksperimen dan Kelas Kontrol

Setelah data berdistribusi normal dan homogen, maka data diuji untuk melihat kemampuan awal sampel dengan menggunakan uji t. Ringkasan uji t dapat dilihat pada Tabel 1 :

Tabel 1. Uji Hipotesis Kemampuan Awal

\begin{tabular}{|c|c|c|c|c|}
\hline No & Data Kelas & $\begin{array}{c}\text { Nilai } \\
\text { Rata-Rata }\end{array}$ & thitung & ttabel \\
\hline 1 & Eksperimen & 11,18 & \multirow{2}{*}{0,1642} & 1,9966 \\
\hline 2 & Kontrol & 11,29 & & \\
\hline
\end{tabular}

Berdasarkan hasil perhitungan menunjukkan bahwa harga thitung $<$ tabel, sehingga dapat diperoleh kesimpulan bahwa antara kelas eksperimen dan kelas kontrol mempunyai kemampuan awal yang sama

Setelah pada kedua kelas sampel diberikan perlakuan yaitu model PBL di kelas eksperimen dan pembelajaran konvensional di kelas kontrol, maka diberikan postes. Nilai ratarata postes kelas eksperimen 77,39 dengan standar deviasi 4,22 dan kelas kontrol 68,71 dengan standar deviasi 5,26. Hasil posttest dapat dilihat seperti Gambar 2.

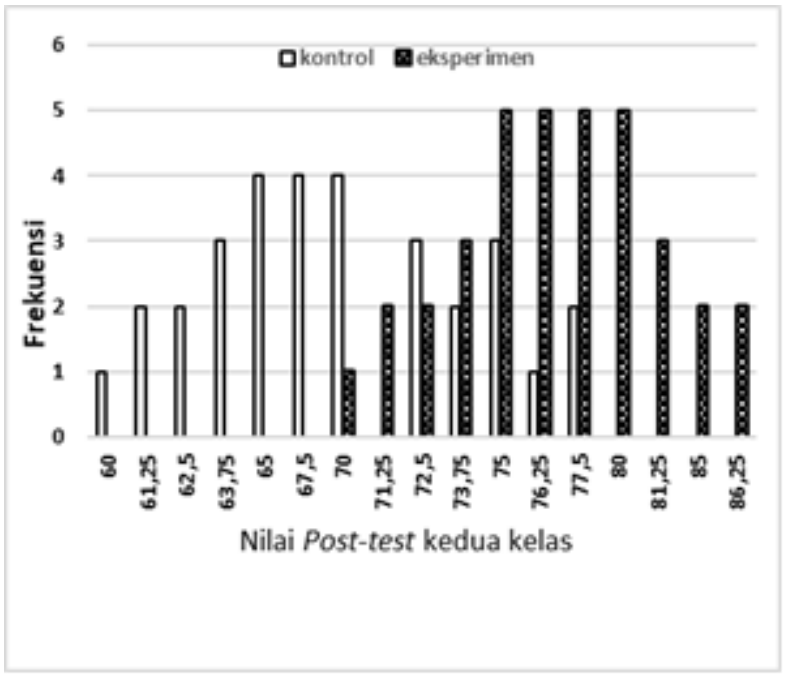

Gambar 2. Data post-test kelas eksperimen dan Kontrol

Setelah data posttest berdistribusi normal dan homogeny maka dilakukan uji hipotesis. Menguji hipotesis digunakan uji $\mathrm{t}$ yaitu untuk mengetahui adanya pengaruh yang signifikan model problem based learning terhadap hasil belajar siswa. Ringkasan perhitungan uji hipotesis untuk kemampuan post-test kelas ekperimen dan kelas kontrol sebagai Tabel 2.

Tabel 2. Perhitungan Uji Hipotesis

\begin{tabular}{|c|c|c|c|c|}
\hline No & Data Kelas & $\begin{array}{c}\text { Nila } \\
\text { Rata- } \\
\text { Rata }\end{array}$ & thitung & ttabel \\
\hline 1 & Eksperimen & 77,39 & \multirow{2}{*}{7,3559} & 1,6687 \\
\hline 2 & Kontrol & 68,71 & \multirow{2}{*}{${ }^{2}$} \\
\hline
\end{tabular}

Berdasarkan tabel 2, perhitungan uji perbedaan nilai rata-rata postes kelas ekperimen dan kelas kontrol, diperoleh thitung> tabel diperoleh kesimpulan bahwa ada pengaruh model problem based learning terhadap hasil belajar siswa pada materi pokok Fluida Statis.

\section{b. Pembahasan}

Berdasarkan uji hipotesis, penerapan model problem based learning dapat meningkatkan hasil belajar siswa. Dibuktikan dengan hasil belajar siswa di kelas eksperimen meningkat lebih baik dibandingkan dengan kelas kontrol serta jumlah siswa yang lulus KKM pada kelas eksperimen lebih banyak daripada kelas kontrol. Hal ini dikarenakan 
siswa pada kelas eksperimen terlibat aktif dalam proses berfikir dan aktif memperoleh pengetahuan.

Besarnya peningkatan hasil belajar peserta didik dikelas eksperimen dikarenakan model problem based learning dapat membantu siswa untuk mencari langsung pengetahuan melalui setiap kegiatan yang telah dirancang pada fase pembelajaran melalui model pembelajaran problem based learning (PBL).

Hosnan (2014) mengidentifikasi model PBL juga berbasis konstruktivistik karena melalui model ini siswa membangun atau mengkonstruk sendiri pengetahuannya.

Menurut Aunurrahman

menjelaskan bahwa dengan menggunakan model PBL dengan tepat dapat memberikan kemudahan bagi siswa untuk memahami pelajaran sehingga memungkinkan siswa untuk mencapai hasil belajar yang lebih baik.

$$
\text { Sejalan dengan Trianto }
$$
menyatakan bahwa ciri-ciri utama pembelajaran berbasis masalah adalah meliputi suatu pengajuan pertanyaan atau masalah, memusatkan keterkaitan antardisiplin. Penyelidikan autentik, kerja sama, menghasilkan karya dan peragaan. Pembelajaran berbasis masalah tidak dirancang untuk membantu guru memberikan informasi sebanyak-banyaknya kepada siswa. Berdasarkan karakter tersebut, pembelajaran berbasis masalah memiliki tujuan:

a. Membantu siswa mengembangkan keterampilan berpikir dan keterampilan pemecahan masalah.

b. Belajar peranan orang dewasa yang autentik.

c. Menjadi pembelajar yang mandiri.

Berdasarkan pembahasan yang telah dipaparkan bahwa model PBL temuan dari penelitian sejalan dengan kajian-kajian teori oleh para ahli. Temuan penelitian juga relevan dengan penelitian terdahulu yang dilakukan oleh Pellawi dan Sinulingga (2016) menunjukkan bahwa terdapat perbedaan pengaruh model PBL dan konvesional terhadap hasil belajar siswa. Penelitian dengan menggunakan model PBL dilakukan juga oleh
Tasoglu dan Bakac (2014) bahwa model PBL dapat meningkatkan hasil belajar dan aktivitas belajar siswa. Penelitian relevan lain yang mendukung yaitu Indagiarmi dan Hakim (2016) menyatakan bahwa model PBL dapat meningkatkan hasil belajar dan penelitian Abdurrozak (2016) menyimpulkan bahwa terdapat peningkatan kemampuan berfikir kreatif dan hasil belajar siswa menggunakan model PBL serta Ibrahim dan Nadjamuddin (2017) yang menyatakan bahwa dengan menggunakan model PBL terbukti dapat meningkatkan hasil belajar siswa.

Pelaksanaan penelitian pada pertemuan pertama tidak berjalan sesuai dengan Rencana Pelaksanaan Pembelajaran (RPP) dikarenakan siswa masih bingung, kaku serta tidak paham dengan proses belajar mengajar yang baru, namun pada pertemuan selanjutnya siswa sudah mulai terbiasa dengan pembelajaran tersebut.

Keseluruhan pembahasan yang telah dikemukakan memberikan keyakinan empirik yang memperkuat keyakinan teoretis bahwa model PBL yang diberlakukan pada kelas eksperimen dapat meningkatkan hasil belajar siswa pada materi fluida statis.

\section{KESIMPULAN DAN SARAN}

Berdasarkan hasil penelitian yang diperoleh dari hasil analisa data dan pengujian hipotesis maka dapat disimpulkan bahwa ada pengaruh yang signifikan model problem based learning terhadap hasil belajar siswa.

Berdasarkan pembahasan hasil penelitian disarankan kepada peneliti selanjutnya hendaknya memberikan penjelasan tentang model dan alat-alat praktikum yang digunakan agar siswa sudah memahami apa yang akan dilakukan sehingga pada proses belajar mengajar waktu belajar lebih efektif dan efisien.

\section{DAFTAR PUSTAKA}

Abdurrozak, R., Jayadinta, A., K., Isrok'atun, I., (2016), Pengaruh model problem based learning terhadap kemampuan berfikir 
Erwin Manik, Togi Tampubolon dan Junita Simanjuntak; Peningkatan Hasil Belajar Dengan Model Problem Based Learning pada Materi Fluida Statis

kritis siswa, Jurnal Pena Ilmiah, 1(1), 871880 .

Arends, R. I., (2008), Learning to Teach (Belajar untuk Mengajar). Yogyakarta: Pustaka Pelajar.

Aunurrahman, (2009), Belajar dan Pembelajaran. Bandung: Alfabeta.

Hosnan, M., (2014), Pendekatan Saintifik dan Kontekstual dalam Pembelajaran Abad 21: Kunci Sukses Implementasi Kurikulum 2013. Jakarta: Ghalia Indonesia.

Ibrahim, A., dan Nadjamuddin, L., (2017), pengaruh model Problem Based Learning terhadap Hasil Belajar Mata Pelajaran Ekonomi pada Siswa SMA Negeri 1 Palu, Jurnal Katalogis, 5(4), 9-19.

Indagiarmi, Y., dan Hakim, (2016), pengaruh model pembelajaran Problem Based Learning (PBL) terhadap hasil belajar siswa kelas XI semester II SMA Swasta Panca Budi Medan pada materi pokok fluida dinamik TP 2014/2015, Jurnal Pendidikan Fisika, 5(1), 26-31.

Pellawi, H., dan Sinulingga, K., (2016), Pengaruh Model Problem Based Learning dan Motivasi Belajar terhadap Hasil Belajar Siswa di Kelas X SMA Swasta Sinar Husni, Jurnal Pendidikan Fisika, 5(1), 3237.

Praharani, Binar, K., W., Soegimin, Yuanita, L., (2015), Pengembangan Perangkat Pembelajaran Fisika Untuk Melatihkan Kemampuan Multi Representasi Siswa SMA, Jurnal Pendidikan Sains Pascasarjana Universitas Negeri Semarang, 503(4), 503-517.

Trianto, (2011), Mendesain Model Pembelajaran Inovatif-Progresif, Kencana : Jakarta.

Tasoglu, A., and Bakac, M., (2014), The Effect of Problem Based Learning Approach on Conceptual Understanding in Teaching of
Magnetism Topics, Eurasian Journal of Physics and Chemistry Education, 6(2), 110-122. 